\title{
A preliminary assessment of the conservation status of the genus Aloe L. in Madagascar
}

\author{
Solofo E. Rakotoarisoa ${ }^{1}$, Ronell R. Klopper ${ }^{2,3}$ \& Gideon F. Smith ${ }^{2,4,5}$
}

1 Millennium Seed Bank Project, Royal Botanic Gardens Kew, Kew Madagascar Conservation Centre, Lot II J 131 B, Ambodivoanjo, Ivandry, Antananarivo, Madagascar.

(email: ESRakotoarisoa.rbgkew@moov.mg).

2 Biosystematics Research and Biodiversity Collections Division, South African National

Biodiversity Institute, Private Bag X101, Pretoria, 0001 South Africa.

(email: R.Klopper@sanbi.org.za).

3 H.G.W.J. Schweickerdt Herbarium, Department of Plant Science, University of Pretoria,

Pretoria, 0002 South Africa.

4 Centre for Functional Ecology, Departamento de Ciências da Vida, Universidade de Coimbra, 3001-455 Coimbra, Portugal. (email: smithgideon1@gmail.com)

5 Department of Botany, P.O. Box 77000, Nelson Mandela Metropolitan University, Port Elizabeth, 6031 South Africa.

Summary: The island of Madagascar harbours 128 species (161 taxa) of Aloe L., which are all endemic to this biodiversity hotspot. Most Malagasy aloes have very restricted distribution ranges and are represented by small populations. Madagascan aloes are very popular in horticulture and an important part of the ornamental plant export industry. The aloes of Madagascar are prone to human pressures that affect the degradation of their natural habitats and their survival. However, there has not been a treatment to assess the conservation status of the Malagasy aloes. Here, for the first time, we aim to provide a risk assessment and make available preliminary conservation statuses for all the known aloes of Madagascar. Specimen information from different herbaria and different websites have been gathered and compiled into a BRAHMS database. The Conservation Assessment Tool was used for data analysis during the conservation assessments. It was found that around 39\% of Madagascan aloes are threatened, with only $4 \%$ being Least Concern. Of great significance is the fact that almost $50 \%$ of the aloes in Madagascar are regarded as Data Deficient, likely leading to a huge underestimate of the percentage of threatened aloes. Further research into Data Deficient taxa and a comprehensive conservation assessment for all the aloes of Madagascar is required. These results will inform priorities in conservation projects concerning aloes and the areas where they occur.
Zusammenfassung: Die Insel Madagaskar ist die Heimat von 128 Arten (161 Taxa) von Aloe L., und alle sind in diesem Biodiversitäts-Hotspot endemisch. Die meisten madagassischen Aloen haben eine sehr beschränkte Verbreitung und sind durch kleine Populationen gekennzeichnet. Madagassiche Aloe-Arten sind im gärtnerischen Bereich geschätzt, und sie stellen einen wichtigen Teil der Zierpflanzenexportindustrie dar. Die Aloen von Madagaskar werden durch anthropogene Faktoren bedrängt, welche zur Degradation ihrer Standorte führen und das Überleben gefährden. Bisher gab es jedoch keine formelle Beurteilung des Gefährdungsstatus' der madagassichen Aloen. Hier versuchen wir für das erste Mal überhaupt eine Beurteilung der Risiken, und wir machen für alle bekannten madagassischen Aloen eine vorläufige Einschätzung des Gefährdungsstandes. Es wurden Angaben zu Belegen aus verschiedenen Herbarien und von verschiedenen Webseiten zusammengetragen und in eine BRAHMS-Datenbank zusammengestellt. Das Werkzeug für die Beurteilung des Gefährdungsstatus wurde dann während der Evaluation zur Datenanalyse verwendet. Es zeigte sich, dass rund 39\% der madagassischen Aloe-Arten gefährdet sind, und nur 4\% gehören in die Kategorie "Least Concern". Von besonderer Wichtigkeit ist die Tatsache, dass für fast 50\% der madagassischen Aloen unzureichende Angaben vorhanden sind, was wahrscheinlich zu einer deutlichen Unterschätzung des Prozentsatzes gefährderter Aloen führt. Es braucht weitere Un- 


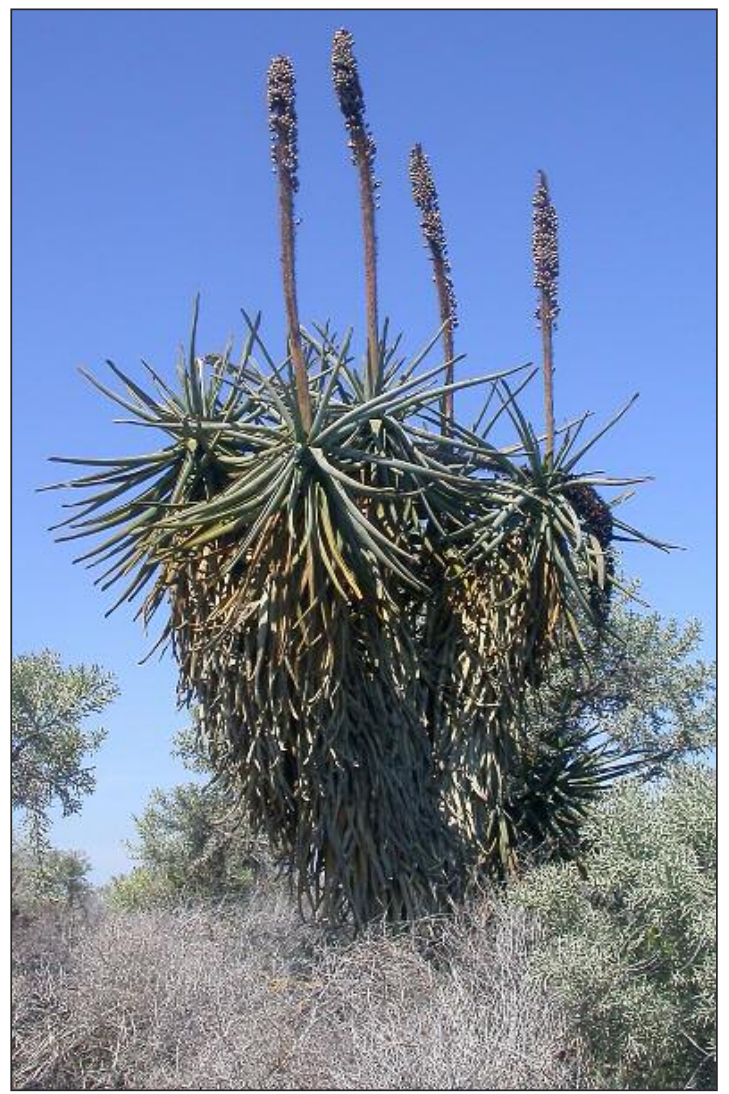

Figure 1. Aloe suzannae from southern Madagascar is one of only two Madagascan aloes currently included in the IUCN Red Data List. It is listed as Critically Endangered.

Photograph: S.E. Rakotoarisoa.

tersuchungen dieser "Data Deficient"-Taxa sowie umfassende Einschätzungen des Gefährdungsstatus' aller madagassichen Aloen. Diese Resultate ergeben die Grundlage für die Prioritätensetzung bei Schutzprojekten für Aloe sowie die Gegenden, in welchen sie vorkommen.

\section{Introduction}

In Madagascar, the genus Aloe L. comprises 128 species and 161 taxa of which all are endemic to the island (Aloes of the World Database, 2014). These plants are highly sought-after by both foreign and Malagasy horticulturists. Aloes represent $5 \%$ of exported succulent ornamental plants, which in turn constitutes $86 \%$ of the total ornamental plants exportation from Madagascar (Rasoanaivo et al., in press).

Scientists have been fascinated by Malagasy aloes for just over 150 years: the first collection of an aloe in Madagascar was made in 1848 by Boivin [Aloe occidentalis (H.Perrier) L.E.Newton \& G.D.Rowley, Boivin, L.H. 2336 (P)]. The first

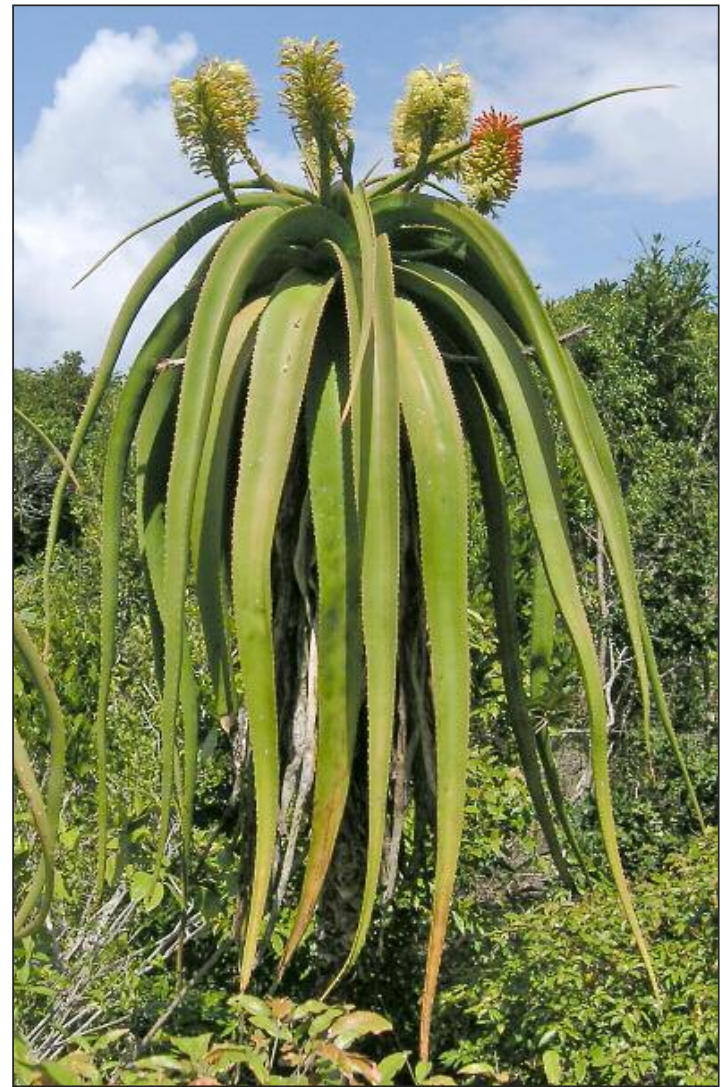

Figure 2. Aloe helenae from southeastern Madagascar is currently listed as Critically Endangered on the IUCN Red Data List.

Photograph: D. Rabehevitra.

treatment of the genus in Madagascar was produced by Perrier de la Bathie in 1926 (Perrier de la Bathie, 1926), followed by an updated Flora treatment in 1938 (Perrier de la Bathie, 1938a $\&$ b). The third treatment of the aloes of Madagascar followed in 1966 when Reynolds produced his epic second volume on the genus (Reynolds, 1966). Thereafter, apart from the inclusion of several aloes in a two volume work on the succulent and xerophytic plants of Madagascar by Rauh (Rauh, 1995, 1998), only small publications describing new aloes appeared. Between 2000 and 2010, approximately 54 new taxa were validly described and eight new combinations published. A further 19 new names, which are now treated as synonyms, were also published during this time (Aloes of the World Database, 2014). The latest large-scale treatment of Madagascan aloes is that of Castillon \& Castillon (2010). Since the appearance of this book, a further fifteen new aloes and two new combinations were published (Aloes of the World Database, 2014) (see Table 1). 


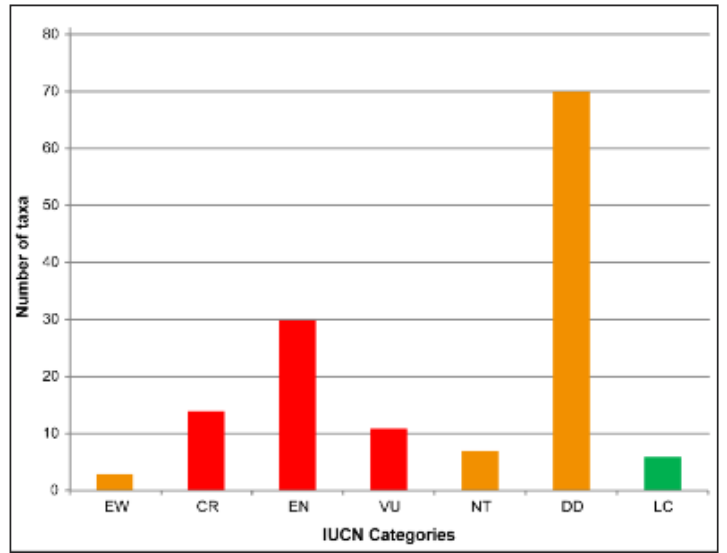

Figure 3. Number of Aloe taxa in the different IUCN categories. (EW: Extinct in the Wild; CR: Critically Endangered; EN: Endangered; VU: Vulnerable; NT: Near Threatened; LC: Least Concerned; DD: Data Deficient)

In Madagascar, research on the genus proves to be challenging, mainly because of the paucity of herbarium material held locally: 95 taxa are represented by only one collection, and 20 species were not collected during the past 40 years. The question remains whether these aloes have disappeared in nature, or if they are only rarely collected by botanists.

Except for a few species (less than 10), the Malagasy aloes have very restricted distribution ranges. Furthermore, most species are represented by a small population. These factors make the genus more vulnerable to human pressures such as bush fires and illegal collecting of wild plants for commercial purposes. In addition, difficulty of regeneration of populations constitutes a real danger of extinction of aloes. The majority of aloes (43\%) are found on the Malagasy high plateau and only $7 \%$ are recorded from the East. Much of the natural vegetation on the central high plateau has been destroyed for rice cultivation and the remaining grasslands are burned annually to provide grazing for zebu (cattle), which play a huge part in the life and rituals of the Malagasy people (Rauh, 1995). The aloes of Madagascar are thus prone to human pressures that affect the degradation of their natural habitats and their survival.

All species of Aloe [except for A. vera (L.) Burm.f] appear on the Appendices of the Convention on the International Trade in Endangered Species of Wild Fauna and Flora (CITES). This means that trade in aloes is controlled to prevent utilisation that would be incompatible with their survival. Of the 21 aloe species listed on Appendix I (CITES, 2014), a total of 17 are Malagasy species. This is an indication of the huge threat

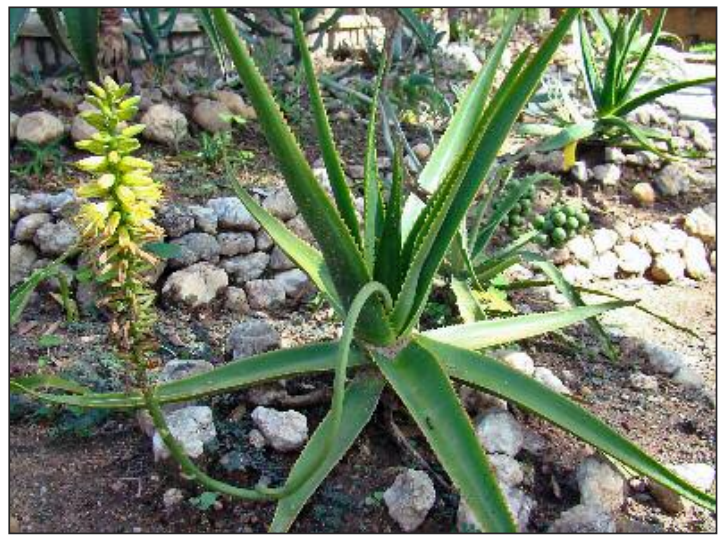

Figure 4. Aloe bernadettae from southeastern Madagascar is a Data Deficient species that used to be common, but has now seemingly become scarce.

Photograph: R. Letsara.

to the conservation of these aloes. All other aloes are listed on Appendix II (CITES, 2014).

Currently, only two Madagascan aloe species appear on the International Union for Conservation of Nature (IUCN) Red Data List, namely Aloe suzannae Decary (Figure 1) (Smith \& Swartz, 1997, 1999; Smith et al., 1999) and A. helenae Danguy (Figure 2), and both are assessed as Critically Endangered D (IUCN, 2014). This list is not up to date as far as the aloes of Madagascar are concerned, owing to the vast number of new aloes described from this island in the past few decades. Another reason is the absence of a full assessment of the conservation statuses of Malagasy aloes. Currently, three Madagascan aloes have become extinct in the wild (namely A. oligophylla Baker, A. schilliana L.E.Newton \& Rowley and A. silicicola H.Perrier), while numerous species are threatened with extinction through the destruction of their natural habitats (Castillon \& Castillon, 2010).

Conservation assessments have become increasingly essential tools to provide a framework for conservation planning, management, monitoring and decision-making (Callmander et al., 2005; Rodrigues et al., 2006). For this reason the World Conservation Congress, held in Thailand in 2004, mandated the development of new applications for Red Lists in national and international legislation, development policies, conservation planning and scientific research (Rodrigues et al., 2006). Even though plants play an essential role in ecosystem structure as the basis of all life on earth, only a small percentage of plants have been assessed globally (Callmander et al., 2005). Therefore, Target 2 of the Global Strategy for Plant Conservation (GSPC) calls for "an assessment of the conservation status of all 


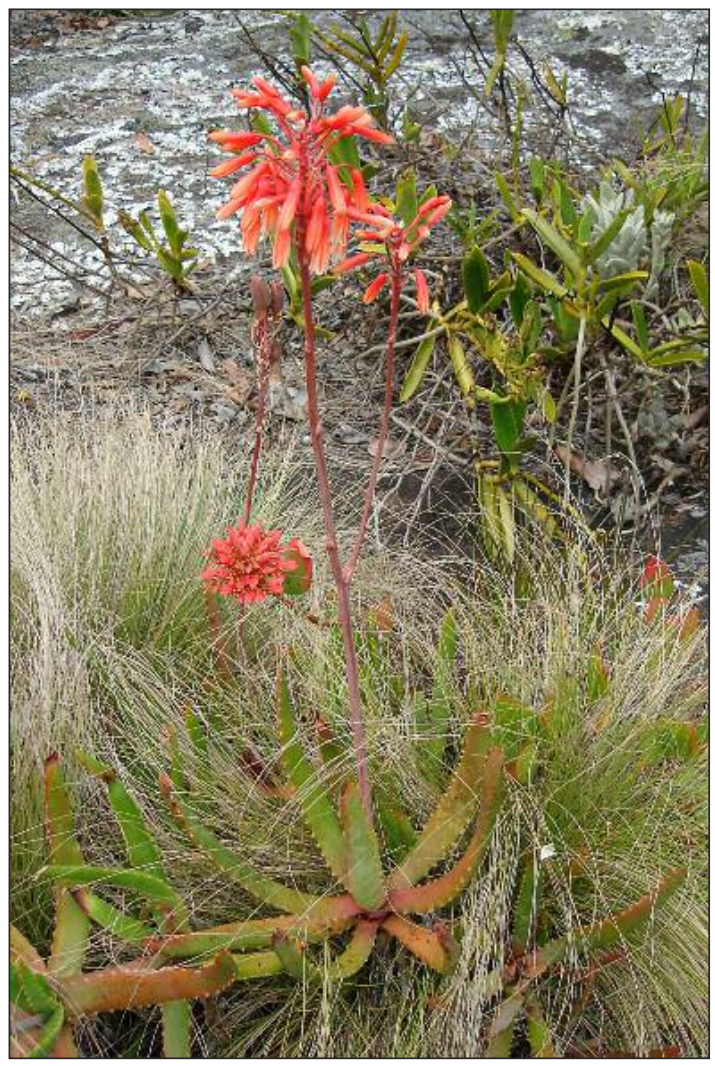

Figure 5. Aloe hoffmannii from central Madagascar is only known from the area of its type locality and is assessed here as Critically Endangered.

Photograph: S.E. Rakotoarisoa.

known plant species, as far as possible, to guide conservation action" (http://www.cbd.int/gspc/targets.shtml). One way of achieving this would be for countries to focus on national endemics that are obvious priorities (Callmander et al., 2005). This approach is especially relevant to the Madagascan aloes, as they are all endemic to this island.

Here, for the first time, we aim to provide a risk assessment and make available preliminary conservation statuses for all the known aloes of Madagascar.

\section{Materials and methodology}

To assemble all the necessary data from herbarium collections, visits were made to various herbaria including the National Herbarium, Pretoria (PRE), and those of the Botanical and Zoological Park of Tsimbazaza (TAN) and the Royal Botanic Gardens, Kew (K). For those herbaria where important Malagasy specimens are held and that could not be visited, available data were downloaded through the Global Biodiversity In-

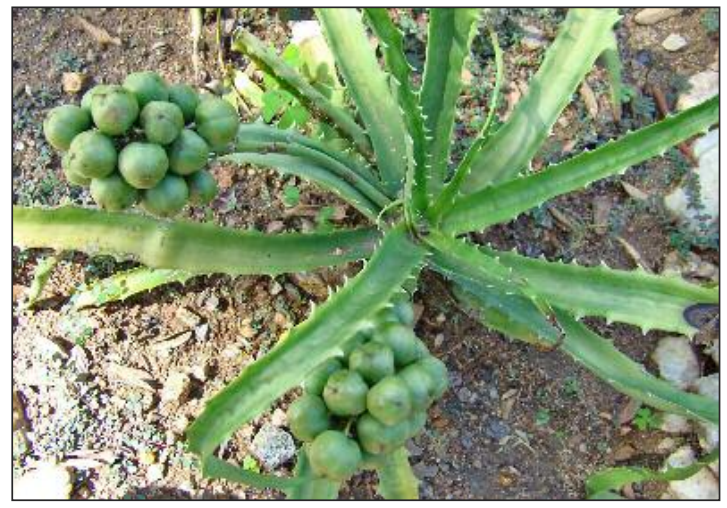

Figure 6. Aloe ivakoanyensis is a berried aloe described in 2012 from the Ivakoany Massiff in southeastern Madagascar and was assessed as Critically Endangered at the time. Photograph: R. Letsara.

formation Facility (GBIF; http://www.gbif.org/) or Sonnerat (http://coldb. mnhn.fr/colweb/form.do ?model=SONNERAT) websites. The final dataset included records from the following herbaria: HBG, K, MO, P, PRE and TAN (herbarium acronyms follow Holmgren et al., 1990). For new taxa where herbarium specimens are not available in the herbaria of Madagascar, information on geographical references, as mentioned in the protologues, was used.

Scientific names of all taxa were updated by referring to the list published by Klopper et al., (2013) and Castillon \& Castillon (2010). This treatment therefore follows all recommendations by Castillon \& Castillon (2010) on synonymy. Hybrids (A. ×anosyana J.-P.Castillon, A. ×philippei J.-B.Castillon, A. Ximerinensis Bosser) were also eliminated from the list. Further updating was based on taxonomic revisions and new descriptions of the Malagasy aloes that were published after 2010 (see Table 1).

Improvements to the georeferencing of especially older specimens were conducted to attain better accuracy for the analyses. This was achieved by manually checking individual collections and correcting all wrong localities and grid references.

ArcView 3.3 and the Conservation Assessment Tool (CAT) were used for the conservation status analysis. Extent of occurrence (EOO) and area of occupancy (AOO) were calculated automatically by the CAT. Default values for grid cells of $2 \times 2 \mathrm{~km}$, as suggested by the IUCN (2001), were used for all situations. As the population size of each species is not yet well defined (possibly being either greater or smaller than $2 \times 2 \mathrm{~km}$ ), EOO values were used for the analysis in this preliminary assessment. 


\begin{tabular}{|c|c|}
\hline Taxon & Citation \\
\hline Aloe antoetrana J.-B.Castillon & CactusWorld 29(1): 53 (2011) \\
\hline Aloe bernardii J.-P.Castillon & International Cactus Adventures 89: 25 (2011) \\
\hline Aloe erythrophylla subsp. major J.-B.Castillon & CactusWorld 29(1): 54 (2011) \\
\hline Aloe mottramiana J.-B.Castillon & CactusWorld 29(4): 218 (2011) \\
\hline Aloe spinitriaggregata J.-B.Castillon & International Cactus Adventures 90: 2 (2011) \\
\hline Aloe $\times$ anosyana J.-P.Castillon & Adansonia 34(1): 20 (2012) \\
\hline Aloe analavelonensis Letsara, Rakotoarisoa \& Almeda & Malagasy Nature 6: 49 (2012) \\
\hline Aloe beankaensis Letsara, Rakotoarisoa \& Almeda & Malagasy Nature 6: 49 (2012) \\
\hline $\begin{array}{l}\text { Aloe divaricata subsp. tulearensis (McCoy \& Lavranos) } \\
\text { J.-P.Castillon }\end{array}$ & Adansonia 34(1): 19 (2012) \\
\hline $\begin{array}{l}\text { Aloe divaricata subsp. vaotsohy (Decorse \& Poisson) } \\
\text { J.-P.Castillon }\end{array}$ & Adansonia 34(1): 18 (2012) \\
\hline Aloe ivakoanyensis Letsara, Rakotoarisoa \& Almeda & Malagasy Nature 6: 52 (2012) \\
\hline Aloe mandrarensis J.-P.Castillon & CactusWorld 30(3): 168 (2012) \\
\hline Aloe virgineae J.-P.Castillon & CactusWorld 30(3): 164 (2012) \\
\hline Aloe conifera subsp. pervagata J.-B.Castillon & CactusWorld 31(1): 45 (2013) \\
\hline Aloe fievetii subsp. johanis-baptistei J-B.Castillon & CactusWorld 31(1): 47 (2013) \\
\hline Aloe graniticola Rebmann & Cactus \& Succulentes 5(2): 52 (2013) \\
\hline Aloe delicatifolia J.-B.Castillon & CactusWorld 31(4): 259 (2013) \\
\hline
\end{tabular}

Table 1. List of new taxa and new combinations published after 2010.

\begin{tabular}{|c|c|}
\hline Species & Infraspecific taxa not assessed separately \\
\hline Aloe antandroi (Decary) H.Perrier & subsp. toliarana J.-B.Castillon \\
\hline Aloe bulbillifera H.Perrier & var. paulianae Reynolds \\
\hline \multirow{2}{*}{ Aloe compressa H.Perrier } & var. paucituberculata Lavranos \\
\hline & var. schistophila H.Perrier \\
\hline Aloe conifera H.Perrier & subsp. pervagata J.-B.Castillon \\
\hline Aloe erythrophylla Bosser & subsp. major J.-B.Castillon \\
\hline Aloe descoingsii Reynolds & subsp. vaotsohy (Decorse \& Poiss.) J.-P.Castillon \\
\hline \multirow{3}{*}{ Aloe fievetii Reynolds } & subsp. johannis-baptistei J.-B.Castillon \\
\hline & var. altimatsiatrae (Rebmann) J.-B.Castillon \\
\hline & var. ambatofinandrahanensis J.-B.Castillon \\
\hline Aloe haworthioides Baker & var. aurantiaca H.Perrier \\
\hline Aloe imalotensis Reynolds & var. longeracemosa J.-B.Castillon \\
\hline Aloe laeta A.Berger & var. maniaensis H.Perrier \\
\hline Aloe sakarahensis Lavranos \& M.Teissier & subsp. pallida (Rauh \& Mangelsdorff) Lavranos \& M.Teissier \\
\hline Aloe trachyticola (H.Perrier) Reynolds & var. multifolia J.-B.Castillon \\
\hline Aloe vaombe Decorse \& Poiss. & var. poissonii Decary \\
\hline Aloe versicolor Guillaumin & var. steffanieana (Rauh) J.-B.Castillon \& J.-P.Castillon \\
\hline
\end{tabular}

Table 2. List of species with infraspecific ranks that were only assessed on species level. 


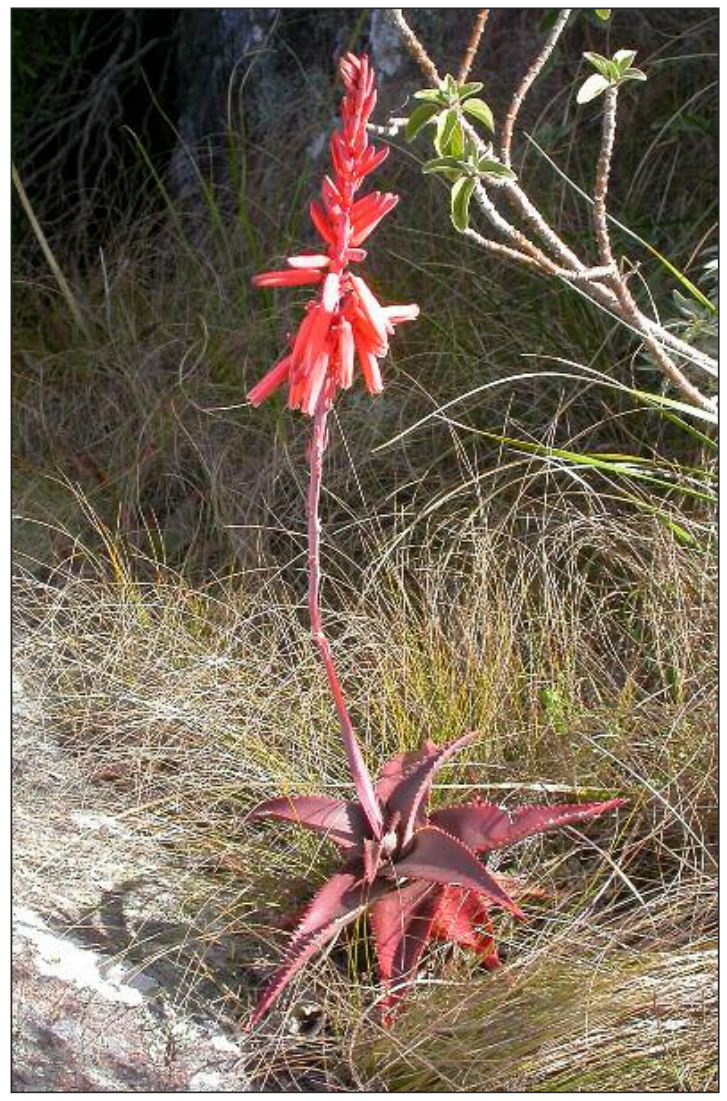

Figure 7. Aloe madecassa is endemic to the Antananarivo region in east-central Madagascar and is here assessed as Vulnerable. Photograph: S.E. Rakotoarisoa.

After preliminary results were obtained, minor corrections were necessary for certain taxa because misidentification of some specimens influenced the distributions. All these cases were treated and corrected individually. Where species had already been assessed by their authors (some newly described species: $A$. virgineae J.-P.Castillon, A. analavelonensis Letsara, Rakotoarisoa \& Almeda, A. beankaensis Letsara, Rakotoarisoa \& Almeda, A. ivakoanyensis Letsara, Rakotoarisoa \& Almeda, Aloe delicatifolia J.-B.Castillon) or IUCN assessors (A. helenae and A. suzannae), we have retained their conservation status as such. In the current study, certain species with infraspecific ranks (e.g. subspecies and varieties) were only assessed to species level if the differences between the lower ranks were not evident on the specimens, or a large part of the collections were only identified up to species level (see Table 2).

\section{Results}

Data from a total of 1630 collections were assembled and compiled into a Botanical Research

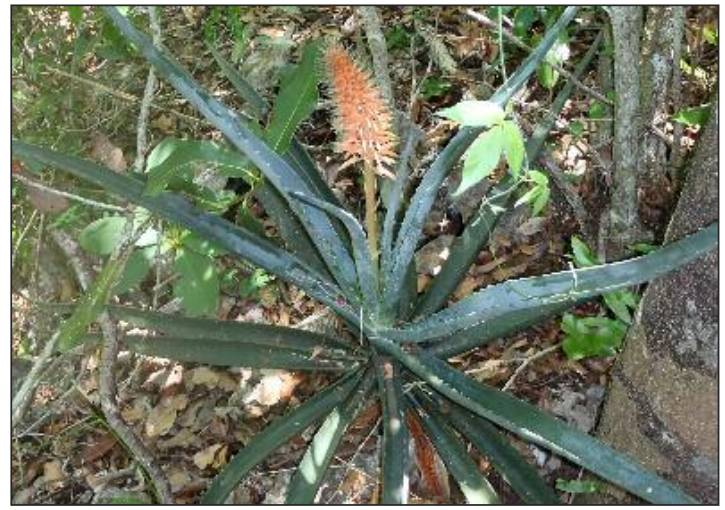

Figure 8. Aloe namorokaensis from northwestern Madagascar is a Data Deficient species that is only known from the type locality. Photograph: Conservatoire

and Herbarium Management System (BRAHMS) database. After updating the identification of some specimens, and eliminating those that were unidentified or not geo-referenced, a total of 759 unique botanical records remained that were used in the analysis. These 759 botanical records include 86 specimens collected by the Millennium Seed Bank Project (MSBP), some of which are already deposited in herbaria in Madagascar or elsewhere, as well as 110 specimens from PRE, 452 from $\mathrm{P}$ (43 downloaded from GBIF), 175 from TAN, 95 from MO (through GBIF), 13 from HBG (through GBIF) and 69 from K. (Several botanical records had duplicate specimens in more than one of these herbaria, therefore the total number of specimens exceeds the number of unique collection records.)

After eliminating all taxa to be excluded from the analysis (synonyms, hybrids and unidentified infraspecific taxa), a total of 141 taxa remained. Of these 141 taxa, a total of 55 (39.3\%) are regarded as threatened (i.e. in the categories Critically Endangered, Endangered or Vulnerable). The taxa of conservation concern are distributed among the different Red List categories as follows: $3(2.1 \%)$ are Extinct in the Wild (EW); 14 (9.9\%) Critically Endangered (CR); 30 (21.3\%) Endangered (EN); 11 (7.8\%) Vulnerable (VU); 7 (5\%) Near Threatened (NT); and 70 (49.6\%) Data Deficient (DD). A further 6 taxa (4.3\%) are Least Concern (LC) (see Figure 3). Percentages given reflect the percentage of the total number of taxa analysed (see Table 3 for a full list of taxa and their conservation statuses).

\section{Discussion and future prospects}

The number of taxa in the DD category is very high because most of these aloes are represented by a single or only two collections. This can be 


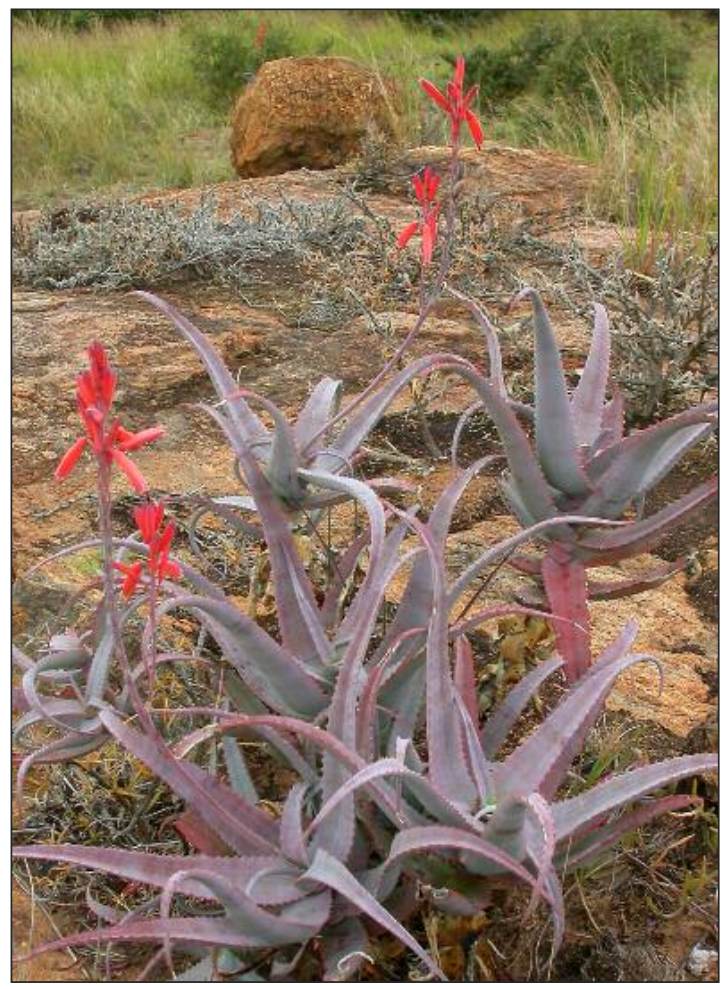

Figure 9. Aloe newtonii from south-central Madagascar is named after Prof. Len Newton. It is here assessed as Endangered.

Photograph: S.E. Rakotoarisoa.

owing to several factors, but the most common is the fact that few botanists collect aloe material as it demands more preparatory treatment and takes a lot of time to make proper herbarium specimens of these fat-leaved plants. A total of $69 \%$ of Madagascan aloes in the DD category are only represented by the type specimen. These include taxa that have been newly described since the 1990s and also a few that have not been collected for more than 100 years. The remaining DD aloes are known from only one or two localities and CAT are thus unable to calculate EOO and AOO values. For the first group, the DD status can easily be explained by their recent discovery and the fact that only a few collections have been made since. However, the problem remains for aloes that were described long ago, but where collection numbers are two or less. These taxa might be very rare, extinct in the wild or access to the populations is very difficult [e.g. Aloe prostrata (H.Perrier) L.E.Newton \& G.D.Rowley].

The difficulty of assessing taxa with few specimens or only old material is a frequent problem and may be relevant to as much as $20 \%$ of the world's plant diversity. If all these taxa are assessed as DD, then the result would be a huge un-

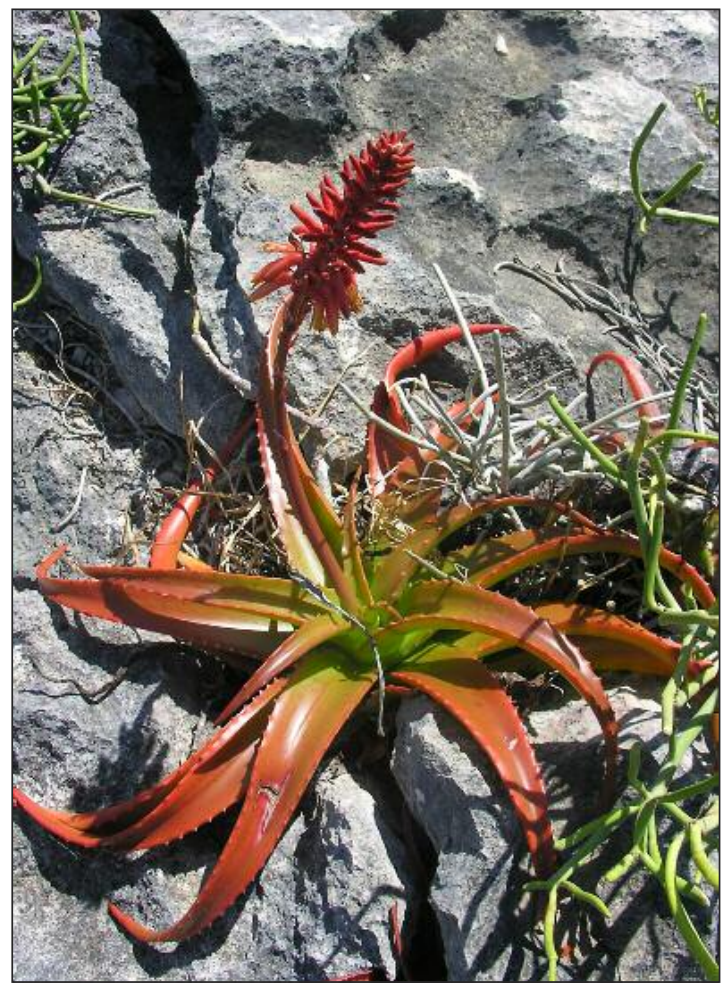

Figure 10. Aloe suarezensis from the Antsiranana region in northern Madagascar is the only Madagascan aloe with fine hairs on the flowers and pedicels. It is here assessed as Endangered.

Photograph: S.E. Rakotoarisoa.

derestimate of the percentage of threatened plants globally. This situation is not very helpful in directly informing conservation planning processes. Such a high proportion of species in the DD category hampers the achievement of the GSPC targets for 2020 (Callmander et al., 2005). For this reason, Callmander et al., (2005) suggested that the DD category should be applied only in cases of unresolved taxonomy or uncertain locality information, and proposed rapid methods for evaluating species with very limited numbers of specimens or only old material. This approach is aimed towards achieving Target 2 of the GSPC.

\section{Table 3. (Overleaf)}

Conservation statuses of Madagascan aloes.

Taxa in threatened categories

(CR: Critically Endangered; EN: Endangered; VU: Vulnerable) are shaded and have status and EOO value in italics.

DD: Data Deficient;

NT: Near-Threatened;

LC: Least Concerned;

EW: Extinct in the Wild;

EOO: extent of occurrence 


\begin{tabular}{|c|c|c|c|c|c|}
\hline Taxon & $\begin{array}{l}\text { IUCN } \\
\text { Status }\end{array}$ & $\begin{array}{c}\text { EOO } \\
\text { value }\left(\mathrm{km}^{2}\right)\end{array}$ & Taxon & $\begin{array}{l}\text { IUCN } \\
\text { Status }\end{array}$ & $\begin{array}{c}\text { EOO } \\
\text { value }\left(\mathbf{k m}^{2}\right)\end{array}$ \\
\hline $\begin{array}{l}\text { Aloe acutissima H.Perrier subsp. } \\
\text { acutissima var. acutissima }\end{array}$ & $V U$ & 15495.83 & $\begin{array}{l}\text { Aloe capitata Baker var. } \\
\text { angavoana J.-P.Castillon }\end{array}$ & $E N$ & 205.22 \\
\hline $\begin{array}{l}\text { Aloe acutissima H.Perrier subsp. } \\
\text { itampolensis Rebmann }\end{array}$ & $\mathrm{DD}$ & \multirow{3}{*}{7567.27} & Aloe capitata Baker var. capitata & $E N$ & \multirow[t]{2}{*}{628} \\
\hline \multirow{2}{*}{$\begin{array}{l}\text { Aloe acutissima H.Perrier var. } \\
\text { antanimorensis Reynolds }\end{array}$} & \multirow{2}{*}{$V U$} & & $\begin{array}{l}\text { Aloe capitata Baker var. } \\
\text { quartziticola H.Perrier }\end{array}$ & NT & \\
\hline & & & \multirow{2}{*}{$\begin{array}{l}\text { Aloe capitata Baker var. silvicola } \\
\text { H.Perrier }\end{array}$} & \multirow[b]{2}{*}{$E N$} & \multirow{2}{*}{334.91} \\
\hline $\begin{array}{l}\text { Aloe acutissima H.Perrier var. } \\
\text { fiherenensis J.-B.Castillon }\end{array}$ & $C R$ & 71.81 & & & \\
\hline \multirow{2}{*}{$\begin{array}{l}\text { Aloe acutissima H.Perrier var. } \\
\text { isaloana J.-B.Castillon }\end{array}$} & \multirow{2}{*}{ DD } & & Aloe castilloniae J.-B.Castillon & $\mathrm{DD}$ & 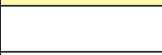 \\
\hline & & & Aloe charlotteae J.-B.Castillon & DD & \\
\hline \multirow{3}{*}{$\begin{array}{l}\text { Aloe albiflora Guillaumin } \\
\text { Aloe albostriata T.A.McCoy, } \\
\text { Rakouth \& Lavranos }\end{array}$} & DD & & \multirow{2}{*}{$\begin{array}{l}\text { Aloe cipolinicola (H.Perrier) } \\
\text { J.-B.Castillon \& J.-P.Castillon }\end{array}$} & \multirow{2}{*}{$E N$} & \\
\hline & \multirow{2}{*}{ DD } & & & & \\
\hline & & & Aloe citrea (Guillaumin) & DD & \\
\hline Aloe alfredii Rauh & DD & & & & \\
\hline Aloe ambositrae J.-P.Castillon & DD & & Aloe compressa H.Perrier & $D U$ & 18782.05 \\
\hline Aloe ambrensis J.-B.Castillon & DD & & Aloe conifera H.Perrier & $E N$ & 4517.56 \\
\hline Aloe ampefyana J.-B.Castillon & DD & & Aloe cryptoflora Reynolds & DD & \\
\hline Aloe analavelonensis Letsara, & & & Aloe cyrtophylla Lavranos & $\mathrm{DD}$ & \\
\hline Rakotoarisoa \& Almeda & $V U$ & & Aloe darainensis J.-P.Castillon & DD & \\
\hline Aloe andringitrensis H.Perrier & $E N$ & 241.88 & Aloe decaryi Guillaumin & $\mathrm{DD}$ & \\
\hline Aloe anivoranoensis (Rauh \& & $\mathrm{DD}$ & & Aloe decorsei H.Perrier & DD & \\
\hline G.D.Rowley & & & Aloe delicatifolia J.-B.Castillon & $E N$ & \\
\hline Aloe ankaranensis Rauh \& & DD & & Aloe delphinensis Rauh & DD & \\
\hline $\begin{array}{l}\text { Mangelsdortt } \\
\text { Aloe antandroi (Decary) H.Perrier }\end{array}$ & NT & & $\begin{array}{l}\text { Aloe deltoideodonta Baker subsp. } \\
\text { amboahangyensis Rebmann }\end{array}$ & DD & \\
\hline Aloe antoetrana J.-B.Castillon & DD & & $\begin{array}{l}\text { Aloe deltoideodonta Baker var. } \\
\text { brevifolia } \text { H.Perrier }\end{array}$ & $E N$ & 3004.69 \\
\hline Aloe antonii J.-B.Castillon & $E N$ & 2914.51 & Aloe deltoideodonta Baker var. & & \\
\hline Aloe antsingyensis (Leandri) & EN & 5507 & candicans H.Perrier & $D U$ & 6114.02 \\
\hline L.E.Newton \& G.D.Rowley & EN & 500.8 & Aloe deltoideodonta Baker var. & $\mathrm{NT}$ & \\
\hline Aloe argyrostachys Lavranos, & DD & & deltoideodonta & & \\
\hline Rakouth \& T.A.McCoy & & & Aloe deltoideodonta Baker var. & $\mathrm{DD}$ & \\
\hline Aloe aurelienii J.-B.Castillon & DD & & fallax J.-B.Castillon & DD & \\
\hline Aloe bakeri Scott-Elliot & NT & & $\begin{array}{l}\text { Aloe deltoideodonta Baker var. } \\
\text { intermedia H.Perrier }\end{array}$ & $E N$ & 1252.35 \\
\hline $\begin{array}{l}\text { Aloe beankaensis Letsara, } \\
\text { Rakotoarisoa \& Almeda }\end{array}$ & $\mathrm{LC}$ & & $\begin{array}{l}\text { Aloe deltoideodonta Baker var. } \\
\text { ruffingiana (Rauh \& Petionat) }\end{array}$ & DD & \\
\hline Aloe belavenokensis & D & & J.-B.Castillon \& J.-P.Castillon & & \\
\hline $\begin{array}{l}\text { (Rauh \& Gerold) L.E.Newton \& } \\
\text { G.D.Rowley }\end{array}$ & DD & & Aloe descoingsii Reynolds & $C R$ & 56.96 \\
\hline Aloe bellatula Reynolds & $V U$ & 9035.22 & $\begin{array}{l}\text { Aloe divaricata A.Berger subsp. } \\
\text { divaricata }\end{array}$ & $\mathrm{LC}$ & \\
\hline Aloe berevoana Lavranos & DD & & Aloe divaricata A.Berger subsp. & & \\
\hline Aloe bernadettae J.-B.Castillon & DD & & $\begin{array}{l}\text { tulearensis (T.A.McCoy \& } \\
\text { Lavranos) J.-P.Castillon }\end{array}$ & DD & \\
\hline Aloe bernardii J.-P.Castillon & $\mathrm{DD}$ & & Aloe divaricata A.Berger subsp. & & \\
\hline Aloe betsileensis H.Perrier & $E N$ & 558.69 & vaotsohy (Decorse \& Poiss.) & $\mathrm{LC}$ & \\
\hline Aloe boiteaui Guillaumin & $\mathrm{DD}$ & & J.-P.Castillon & & \\
\hline Aloe bosseri J.-B.Castillon & $\mathrm{DD}$ & & $\begin{array}{l}\text { Aloe droseroides Lavranos \& } \\
\text { T.A.McCoy }\end{array}$ & DD & \\
\hline Aloe bruynsii P.I.Forst. & $\mathrm{DD}$ & & Aloe edouardii Rebmann & $E N$ & 111.64 \\
\hline Aloe buchlohii Rauh & DD & & Aloe ericetorum Bosser & $\mathrm{DD}$ & \\
\hline Aloe bulbillifera H.Perrier & NT & & Aloe erythrophylla Bosser & $E N$ & 179.52 \\
\hline Aloe calcairophila Reynolds & $C R$ & 2.57 & $\begin{array}{l}\text { Aloe eximia Lavranos \& } \\
\text { T.A.McCoy }\end{array}$ & DD & \\
\hline
\end{tabular}




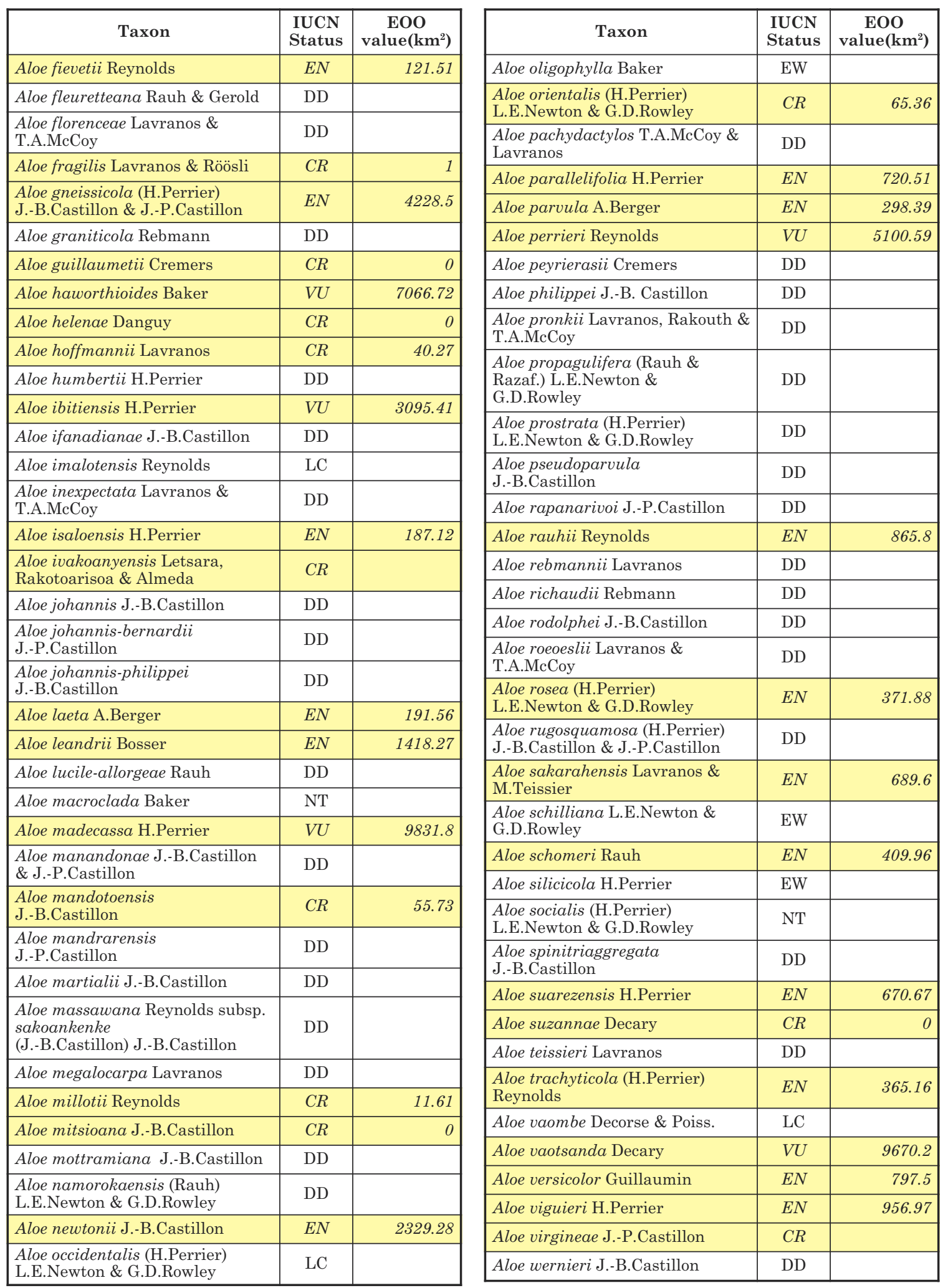




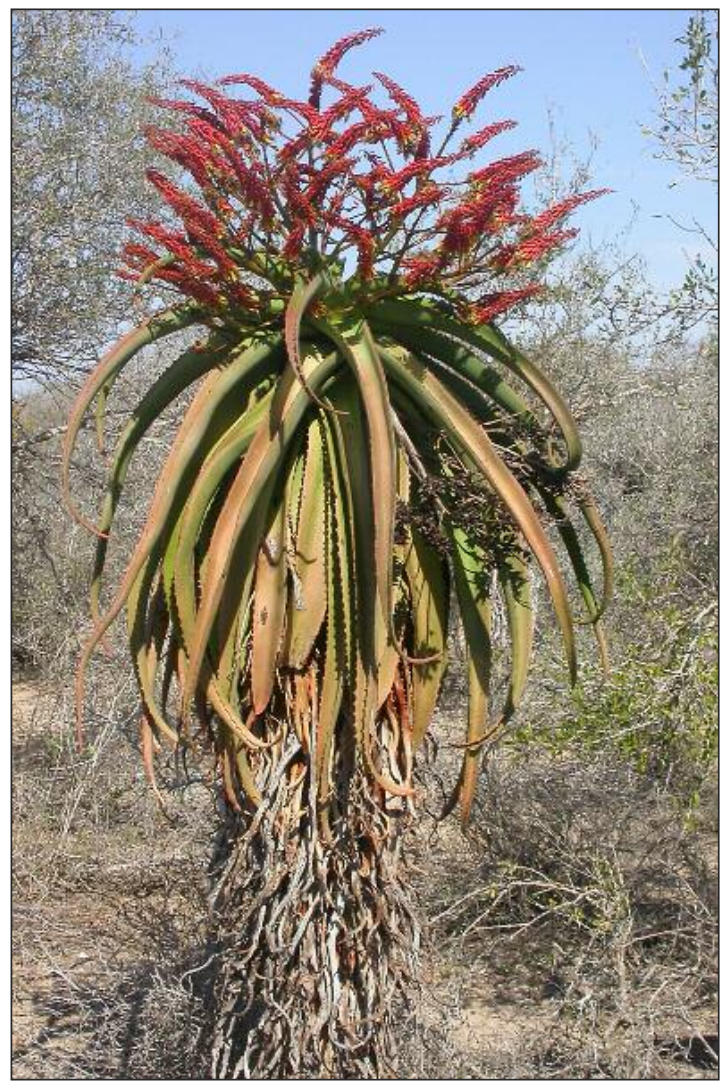

Figure 11. Aloe vaotsanda from southern Madagascar is here assessed as Vulnerable. The stems of this aloe are used in the construction of huts.

Photograph: S.E. Rakotoarisoa.

Examples of taxa that can be assessed in this way include taxa that are known only from type specimens collected over a 100 years ago in environments that have since become urban areas, as well as taxa that were only collected at a single locality that has now been transformed into degraded or fragmented habitat, but still with some native vegetation (Callmander et al., 2005). These methods could well be applied to a large number of the Madagascan aloes that are here ascribed to the DD category. However, at this preliminary stage, these taxa remain in this category. During a full conservation assessment, they could well be classified in other categories (EX, CR, EN or VU).

Fieldwork to obtain more data for these DD taxa must therefore be a priority for future study. Precedence should also be given to the identification of specimens of taxa with infraspecific ranks where the collections remain identified only to species level, before further assessments can be done regarding the conservation of these aloes. The number of taxa in the threatened categories may change in a comprehensive assessment of their conservation status, because the majority of these taxa have very restricted distribution ranges. Therefore, with further investigation it could, for example, be ascertained that the size of each population is less than $2 \times 2 \mathrm{~km}$. At such time the analysis will be based on the value of AOO, rather than EOO (see Materials and Methodology section for an explanation).

One of the major difficulties faced during this assessment was to update the identification of specimens. This was especially problematic for species with infraspecific ranks where there are no easily observed distinguishing morphological characters that allow identification of herbarium specimens to the lowest taxonomic rank. Identifications of some infraspecific taxa could only be updated based on distribution, where the varieties or subspecies are divided by inter alia geographical barriers, rather than clear morphological discontinuities. For this reason the assessment was only carried out at species level for some taxa.

The low number of taxa in the NT and LC categories indicates that only a few taxa are widely distributed. Because of their restricted distribution ranges, the survival of most Madagascan aloes will be severely impacted in the presence of threats such as human activities (illegal collecting, agricultural practices) and cataclysm (flood, cyclone, prolonged drought). The main threats identified thus far are illegal harvesting of plants in their natural habitat and mining activities.

\section{Conclusions}

The assessment results presented here are preliminary and are obtained from $\mathrm{AOO}$ and $\mathrm{EOO}$ values, with the exception of a few recently described taxa where a conservation status has already been determined by their authors. These preliminary results are based largely on an assessment of herbarium collections that provide limited population-level data, which is an important parameter for assessing conservation status. For this reason, these results may change during the full conservation assessment that will be conducted. Such a comprehensive assessment will require extensive research concerning the populations and threats of each aloe before assigning a final status. At that stage, niche modelling software (e.g. Maxent) will be used for predictive mapping in order to assist in the search for additional unknown populations and in producing conservation plans for a species. Nonetheless, the preliminary assessment already provides a realistic picture of the conservation status of Madagascan aloes. It also highlights the need to urgently update the full conservation assessments for the Malagasy aloes, which will contribute to- 
wards reaching Target 2 of the GSPC. This is especially important since only two Malagasy species are currently included in the IUCN Red List of Threatened Species (IUCN, 2014). In addition, these two aloes were evaluated more than 15 years ago and the assessments need to be updated.

The information presented here further enables prioritising of actions in conservation projects concerning aloes. At present several aloe sites are subject to destruction because of mining operations (e.g. A. conifera H.Perrier subsp. pervagata J.-B.Castillon and A. guillaumetii Cremers) or the clearing of land for agricultural purposes. The vast majority of Madagascan aloes are in the category of Data Deficient (DD). These species deserve special attention as it is suspected that a large majority of the DD aloes could be threatened.

\section{Acknowledgments}

Curators of the herbaria from which specimens were studied (see Materials and Methodology section) are thanked for enabling access to their collections. We would also like to express our gratitude to Dr Mijoro Rakotoarinivo, Kew Madagascar Conservation Centre and Mr Stuart Cable, Royal Botanic Gardens, Kew, for guidance and advice during the initial stages of the project.

\section{References}

Aloes of the World Database. (2014). Unpublished database of the Aloes of the World Project. SANBI, Pretoria. Accessed April 2014.

Callmander, M.W., Schatz, G.E. \& Lowry II, P.P. (2005). IUCN Red List assessment and the Global Strategy for Plant Conservation: taxonomists must act now. Taxon 54: 1047-1050.

Castillon, J.-B. \& CAstillon, J.-P. (2010). Les aloe de Madagascar / The aloe of Madagascar. J.-B. \& J.-P. Castillon, Reunion.

CITES. (2014). CITES Appendices I, II and III. Available: http://www.cites.org/eng/app/appendices.php. Accessed April 2014.

Holmgren, P.K., Holmgren, N.H. \& Barnett, L.C. (1990). Index herbariorum, part 1: The herbaria of the world, 8th edn. New York Botanical Garden, New York.

IUCN. (2001). IUCN Red List Categories and Criteria: Version 3.1. IUCN Species Survival Commission. IUCN, Gland, Switzerland and Cambridge, UK.

IUCN. (2014). IUCN Red List of Threatened Species. Version 2013.1. Available: http://www.iucnredlist.org. Accessed April 2014.
Klopper, R.R., RAKotoarisoA, S.E. \& SMith, G.F. (2013). Checklist of the aloes of Madagascar and the Western Indian Ocean Islands: towards and interactive identification mechanism. In: Beau, N., Dessein, S. \& Robbrecht, E. (EDS), African Plant Diversity, Systematics and Sustainable Development-Proceedings of the XIXth AETFAT Congress, held at Antananarivo, Madagascar, 26-30 April 2010. Scripta Botanica Belgica 50: 263-271. National Botanic Garden of Belgium, Meise.

Perrier de la BAthie, H. (1926). Les Lomatophyllum et les Aloe de Madagascar. Mémoires de la Société Linnéenne de Normandie 1: 1-59.

PERRIER DE LA BAthie, H. (1938a). Liliacées: Aloineae: Lomatophyllum. Flore de Madagascar 40 Famille: 69-76. Imprimerie Officielle, Tananarive.

Perrier de la BAthie, H. (1938b). Liliacées: Aloineae: Aloe. Flore de Madagascar 40 Famille: 77-112. Imprimerie Officielle, Tananarive.

RASOANAIVO, F.H., RAMAROSANDRATANA, A.V., RAKOUTH, B. \& RaVAOMANALINA, B.H. (In press). International trade of malagasy Aloe species as ornamental plant. University of Antananarivo, Department of Plant Biology and Ecology, Antananarivo.

RAUH, W. (1995). Succulent and xerophytic plants of Madagascar. Volume 1. Strawberry Press, California.

RAUH, W. (1998). Succulent and xerophytic plants of Madagascar. Volume 2. Strawberry Press, California.

REYNolds, G.W. (1966). The aloes of tropical Africa and Madagascar. Aloes Book Fund, Mbabane.

Rodrigues, A.S.L., Pilgrim, J.D., Lamoreux, J.F., Hoffmann, M. \& Brooks, T.M. (2006). The value of the IUCN Red List for conservation. Trends in Ecology \& Evolution 21: 71-76.

Smith, G.F., Steyn, E.M.A. \& Coetzee, J. (1999). Morpho-anatomical leaf features of Aloe suzannae Decary (Asphodelaceae). In: TimBerLAKE, J. \& KATIVU, S. (EDS). African plants: biodiversity, taxonomy and uses. Royal Botanic Gardens, Kew. pp. 409-421.

Smith, G.F. \& Swartz, P. (1997). Re-establishment of Aloe suzannae in Madagascar. Part 1. The way to the Red Island. British Cactus \& Succulent Journal 15: 88-93.

SMith, G.F. \& SwarTZ, P. (1999). Re-establishing Aloe suzannae in Madagascar. Part 3. The next chapter. British Cactus \& Succulent Journal 17: 45-49. 